\title{
Research on the Connotation and Development Path of Mission Education for Chinese College Students in the New Era
}

\author{
Lin Jiang1,2 \\ ${ }^{1}$ Yancheng Teachers University, Yancheng, China \\ ${ }^{2}$ Nanjing University of Aeronautics and Astronautics, Nanjing, China \\ Email: jiangl@yctu.edu.cn
}

How to cite this paper: Jiang, L. (2022). Research on the Connotation and Development Path of Mission Education for Chinese College Students in the New Era. Open Journal of Social Sciences, 10, 326-342.

https://doi.org/10.4236/jss.2022.102024

Received: January 27, 2022

Accepted: February 22, 2022

Published: February 25, 2022

Copyright $\odot 2022$ by author(s) and Scientific Research Publishing Inc. This work is licensed under the Creative Commons Attribution International License (CC BY 4.0).

http://creativecommons.org/licenses/by/4.0/

\begin{abstract}
This paper studies the connotation and development path of mission education for Chinese college students in the new era. Using the mission descriptions of 50 colleges and universities selected from the top 100 colleges and universities in China on the website of "China Education Online" as the research object, the research method of text frequency analysis and cluster analysis is used to search for key phrases, refine key words and form the connotation categories of mission education by clustering, and the mission education system is constructed, which includes world mission, national mission, political party mission, social mission, college mission, discipline mission and talent mission. Through the process of searching key phrases, refining key words and forming mission education connotation categories by clustering, we constructed a mission education system for Chinese college students in the new era, which includes global mission, national mission, political party mission, social mission, college mission, discipline mission and talent mission, and explored the development path of mission education for Chinese college students based on seven mission categories.
\end{abstract}

\section{Keywords}

New Era, Chinese University Students, Textual Analysis, Mission Education, Development Path

\section{Introduction}

On September 12, 1997, in the report of the 15th National Congress of the Communist Party of China, it was proposed for the first time that "a moderately 
prosperous society will be fully built in 2021, one hundred years after the founding of the Communist Party of China, and a rich, strong, democratic, civilized and harmonious socialist modern country will be built in 2049, one hundred years after the founding of New China." In 2012, the 18th National Congress of the Communist Party of China issued a call of the times to the Chinese people to march towards the goal of "two hundred years", and "two hundred years" has since become a fixed keyword and a common goal for all Chinese people of all nationalities. The year 2021 marks the 100th anniversary of the founding of the Communist Party of China, and the period 2021-2025 is the historical intersection of the "two hundred years". Entering into the new development stage of the second hundred-year dream, the new development concept has a new development in terms of historical orientation, requirements of the times, thinking methods and international environment. To implement the new development concept, we need to further summarize the economic and social development, the progress of a strong country, the values and the historical process of human beings, further focus on the transformation of the main social contradictions in the development of China and the historic leap from "rich" to "strong", and further systematically the "two hundred years" goal, domestic and international "two big situations" and the new development concept "five in one" are coordinated, and security and development are further integrated to better grasp the international changes and domestic environment (Zhang, 2021). At this historical intersection, it is emphasized that mission education should be comprehensive, multi-level and three-dimensional, and its scope should not be limited to party and government leaders, but also include university students. The new era has given more groups with higher mission requirements, and mission education should be studied.

The mission education for college students is a strategic need to create the new man of the age who can assume the great responsibility of national rejuvenation, an important content of ideological and political education in colleges and universities, and has a distinct logic of reality (Li \& Sun, 2021). The literature (Wang, 2021a) believes that integrating mission education in colleges and universities into students' activities is conducive to helping college students get out of the virtual network space, return to the rich real life, establish correct worldview, outlook on life and values, and grow up to be the new man of the times who can take up the responsibility of national rejuvenation. Literature (Wang, 2021b) suggests that young people are the driving force for the great rejuvenation of the nation, and to promote the innovation of the ideological and political theory courses in the new era, it is necessary not only to highlight the "mission education" in the educational content, but also to take care of the distinctive characteristics of young people in the new era. Literature (Han \& Yao, 2021) argues that "not forgetting the original intention and remembering the mission" is a lifelong issue for all Party members and cadres, and the leadership of the Communist Party of China requires the formation of an institutionalized education mechanism. Literature (Xu, 2021) suggests that Marx and Engels' 
mission concept reveals the mission of the proletariat and its political parties, and believes that the mission subject and mission content are inherently prescriptive, and that the mission of the proletariat and its political parties is determined by its class attributes, social status and the laws of movement of the basic social contradictions. Literature (Huang \& Wang, 2021) points out that the report of the 19th Party Congress puts forward the strategic task of "cultivating new generations to assume the great responsibility of national rejuvenation", and for the first time, the historical mission of "national rejuvenation" is taken as the connotation of "new generations". The connotation of "national rejuvenation" is the first time that the historical mission of "national rejuvenation" is the connotation of "new man of the times". The literature (Yu \& Wu, 2020) suggests that professional mission education aims to integrate the education of ideals, beliefs and values into professional teaching, cultivate students' sense of professional mission and honor, and provide students with "professional identity education", "professional skills education" and "craftsmanship education". "artisan spirit education". The literature (Flavin, Zhou, \& Quintero, 2020) analyzed $76.048 \%$ of the mission statements of 127 UK higher education institutions in the mainstream higher education sector and summarized the57 most common terms based on the statements. The literature (Emini \& Ayaz, 2020) analyzed the mission statements of state and basic universities operating in Turkey and the context and frequency of the use of concepts related to innovation, revealing the differences and similarities between state and basic universities. The literature (Wang \& Guo, 2020) states that one of the most important missions of universities is to develop human resources for the society and that students should be considered as partners and customers of the university and that student satisfaction and employability should be given top priority. The literature (Ostatnikova, Hopkins, Robinson, \& Hnilicova, 2019) argues that universities and their educational mission in the 21st century include increasing student enrollment and building a knowledge-based society, integrating digital media and transforming learning into the acquisition of specific skills, social networking competencies, and digital capabilities. It can be seen that many researchers have realized that the mission education of university students is becoming more and more important and diversified, one is the need to fulfill the historical tasks of the times; the second is the need to play the historical role of youth; the third is the need to build the ideological foundation of youth; the fourth is the need to cultivate the innovative thinking and ability of youth; the fifth is the need to nurture the excellent character of youth; the sixth is the need to lead youth to pass on their culture; the seventh is the need to encourage youth to Seventh, it is the need to encourage young people to integrate into society, and eighth, it is the need to enhance the courage and spirit of young people to strive for the glory of the country. If the youth are strong, the country will be strong; if the youth are brave enough to bear the burden of the country, there will be hope for the development of the country. However, there is no literature to form a system of mission education for college students. Mission education is not only a question of the 
direction of colleges and universities and college students' training, but also a question of the fundamental interest driving the future national development pattern and world development pattern, so this paper will adopt the method to refine the system of mission education for Chinese college students. The current mission education system of college students is imperfect and unclear, the teachers may be part-time, and the attention is obviously insufficient. It is necessary to summarize the current situation of mission education of college students and design a framework for mission education of college students in the future, so that college students can shoulder the mission and struggle better.

\section{The Meaning of Mission Education for College Students}

In this paper, 50 colleges and universities were selected from the top 100 colleges and universities nationwide on the website of "China Education Online" according to their geographical situation, taking into account most of the provincial administrative regions in China. Among the 50 universities, $66 \%$ are comprehensive universities, $26 \%$ are science and technology universities, $4 \%$ are finance and economics universities, and $4 \%$ are teacher training universities. The sample of 50 colleges and universities are almost all "211 Project" colleges and universities and "double first-class" colleges and universities, representing the tip of the pyramid of China's college development, which is very representative. If mission education is to be carried out, it should also be carried out from these outstanding universities first. The more outstanding talents, the more they need to improve their ideological and moral cultivation and mission education, so as to understand great virtues and take up great responsibilities. I searched the descriptions on the websites of the 50 universities one by one about the mission of the school, and listed the mission key phrases according to the descriptions, as shown in Table 1.

Text analysis is one of the more common and important methods of literature research. In this paper, after completing the content codification, we mainly use the text frequency analysis and cluster analysis to study the mission education of college students.

\subsection{Basic Characteristics of College Students' Missions Based on Frequency Analysis Method}

In this paper, Gooseeker software was used to perform subword processing, synonym merging, and frequency analysis on mission description key phrases, and keywords with frequencies greater than 5 in all university missions were selected, as shown in Table 2.

\subsection{Cluster Analysis Based on Co-Linear Matrix}

Based on Gooseeker software, the high-frequency keywords in Table 2 were co-word matched to form a co-linear matrix. The co-linear matrix was input in-

to Gephi software for statistical analysis and cluster analysis, and the average 
Table 1. Key phrases of mission description for a sample of 50 universities.

\begin{tabular}{|c|c|}
\hline $\begin{array}{c}\text { Serial } \\
\text { number }\end{array}$ & Mission Description Key Phrases \\
\hline $\mathrm{U} 1$ & $\begin{array}{l}\text { World-renowned high-level university; research; the forefront of world-class universities; the construction } \\
\text { of world-class universities with Chinese characteristics; the Chinese dream of the great rejuvenation of the } \\
\text { Chinese nation. }\end{array}$ \\
\hline $\mathrm{U} 2$ & $\begin{array}{l}\text { To collect the greatness of ideas; to nurture the pillars of the nation; to open up the precedent of academics; } \\
\text { to promote the progress of science and technology; to lead the direction of society. }\end{array}$ \\
\hline $\mathrm{U} 3$ & $\begin{array}{l}\text { To build up virtue and educate people; to be a university that satisfies the people; to seek the well-being of } \\
\text { mankind, promote social progress and achieve national prosperity; to be pragmatic, pioneering and } \\
\text { pursuing excellence; to be a world-class university with Chinese characteristics. }\end{array}$ \\
\hline $\mathrm{U} 4$ & $\begin{array}{l}\text { High-quality, creative talents; the frontier of scientific research; an important base for knowledge innovation; } \\
\text { an important bridge and window for international exchange. }\end{array}$ \\
\hline U5 & $\begin{array}{l}\text { Right direction; moral education; service to the country; reform and innovation; comprehensive reform and } \\
\text { "double first-class" construction; connotative development; world-class university; national development, } \\
\text { people's happiness and progress of human civilization. }\end{array}$ \\
\hline U6 & $\begin{array}{l}\text { Socialist direction with Chinese characteristics; moral and talent, leadership and family; major national } \\
\text { strategic needs; national and regional economic and social development; academic frontier; people's life and } \\
\text { health. }\end{array}$ \\
\hline U7 & $\begin{array}{l}\text { National high-level university construction; based in Hunan, facing the whole country, looking at the world; } \\
\text { comprehensive reform and internal development within the university; distinctive world-class university; } \\
\text { Chinese dream of great rejuvenation of the Chinese nation. }\end{array}$ \\
\hline U8 & $\begin{array}{l}\text { Energetic spirit and simple and plain working style; the spirit of General Secretary Xi Jinping's instruction; } \\
\text { internal development; characteristics; world-class university; great rejuvenation of the Chinese nation. }\end{array}$ \\
\hline U9 & $\begin{array}{l}\text { Innovation, coordination, green, openness and sharing; comprehensive improvement of talent cultivation } \\
\text { quality; comprehensive deepening of comprehensive reform; comprehensive promotion of the rule of law; } \\
\text { scientific level of Party building; distinctive world-class university. }\end{array}$ \\
\hline U10 & $\begin{array}{l}\text { Cultivate talents; serve national defense construction and national and local economic construction; } \\
\text { strengthen basic frontier cross-sectional research; forge ahead; innovate; world class university with Chinese } \\
\text { characteristics. }\end{array}$ \\
\hline U11 & $\begin{array}{l}\text { Xi Jinping Thought on Socialism with Chinese Characteristics in the New Era; Knowledge; Culture; Society; } \\
\text { Quality; Excellence; Respect; Dream; World-class University; Great Revival of the Chinese Nation; } \\
\text { Progress of Human Civilization. }\end{array}$ \\
\hline $\mathrm{U} 12$ & $\begin{array}{l}\text { Xi Jinping Thought on Socialism with Chinese Characteristics in the New Era; Keeping the Righteousness } \\
\text { and Innovation, Pursuing Excellence, Striving for the Future; Establishing Virtues for People; World-class } \\
\text { University with Chinese Characteristics; Modernizing and Strengthening the Country; Great Revival of the } \\
\text { Chinese Nation. }\end{array}$ \\
\hline U13 & $\begin{array}{l}\text { Xi Jinping Thought on Socialism with Chinese Characteristics in the New Era; Rooted in the Land of China; } \\
\text { Historical Mission; First-class Goals; First-class Performance; Cultural Heritage; World-class University with } \\
\text { Chinese Characteristics; Great Revival of the Chinese Nation. }\end{array}$ \\
\hline $\mathrm{U} 14$ & $\begin{array}{l}\text { Academics; Talents; Reviving the nation; Development; Excellence; People-centered; Never forget the original } \\
\text { intention and remember the mission; Chinese characteristics; World-class universities; High quality; } \\
\text { Nurturing people for the Party and the country. }\end{array}$ \\
\hline
\end{tabular}


To promote education and strengthen the country; to seek truth from facts; to be rigorous; to be patriotic and dedicated; to be determined to innovate; to have distinctive disciplinary features; to have domestic first-class education quality and research level; to have international influence; to be of high level.

Passing on civilization; seeking truth; revitalizing China; benefiting humanity; world-class university with Chinese characteristics.

World-class university; Thick learning, seeking for innovation; daring to compete, good at transformation, concentrating on scientific development.

Unity, diligence, rigor, innovation; virtue and erudition, dedication and joy; dedication and pursuit of excellence; world-class university with information technology characteristics.

Learn, think, discern, act; be virtuous, learn, be strong, be pragmatic, innovative, and pursue excellence; academic, good governance, happiness, and great beauty; world-class university with Chinese characteristics; and the Chinese dream of great rejuvenation of the Chinese nation.

Inclusive and generous, enterprising; diversified culture; multidisciplinary intersection, complementary; characteristic culture; seeking and taking charge; faithful and benevolent, deliberate and diligent; cultural construction and cultural leadership.

Socialist Thought with Chinese Characteristics in the New Era of Xi Jinping; Belt and Road; Strong Nation; Economic Circle Construction; National Strategy; Comprehensive Deepening Reform and Rule by Law; "Double First Class", Special Features and High Quality; Chinese Dream of Great Revival of the Chinese Nation.

Socialist Thought with Chinese Characteristics in the New Era of Xi Jinping; World Science and Technology First-Class Disciplines; Great Revival of the Chinese Nation.

Walking with the motherland; helping the world with science and education; world-class university with Chinese characteristics.

National spirit and social responsibility; international vision and sense of cooperation and competition; scientific spirit and humanistic literacy; innovation consciousness and practical ability; leading talents and backbone strength; world-class university with remarkable characteristics.

Talented university, quality university, culture university; domestic first-class; internationally renowned high-level university; high-quality innovative and entrepreneurial talents; high-level scientific research; high-tech research and development; high-level decision-making consultation.

National Destiny; National Strategy; Satisfaction of the Party and the State; Social Responsibility; Satisfaction of the general public; People-oriented; Fundamental interests of the school's faculty, students and staff; Satisfaction of the general faculty, students and staff.

To serve the major national strategies; socialist direction of schooling; moral education; a comprehensive U27 research university with distinctive features, domestic first-class and internationally renowned; the Chinese dream of great rejuvenation of the Chinese nation.

Xi Jinping Thought on Socialism with Chinese Characteristics in the New Era; Establishing morality and cultivating people; An excellent university that satisfies the people and is admired by the world; Creating advantages with characteristics; A world class university with distinctive characteristics.

Inherit the red gene; establish moral education; distinctive world-class university; national major development strategy needs; comprehensive reform; internal characteristics.

Xi Jinping Thought on Socialism with Chinese Characteristics in the New Era; Aiming at the Frontier;

U30 Serving Strategy; Interdisciplinary; Industry-University-Research; Internationalization; Comprehensive Reform; Major Breakthrough; Chinese Characteristics; People's Satisfaction; World-class University. 
Establishing morality; strengthening talents; integrating industry and education; educating people; leading with innovation; reforming; seeking truth and pragmatism; pioneering and innovating; world-class university.

Quality school; strong talent; service school; mechanism living school; culture casting school; world-renowned, China's first-class; research; world-class discipline construction; great rejuvenation of the Chinese nation.

Faithfulness and respect, knowledge and action, self-improvement, harmony and difference; quality is the life; innovation is the soul; advancing with the times, pioneering and innovative; domestic first-class; world-renowned; high-level university.

Establishing virtue and cultivating people; indomitable; rigid and heavy, brave to bear the heavy load; characteristic development; connotation development; innovative development; high quality talents; serving economic and social development; distinctive; high level; applied research-oriented.

Xi Jinping Thought on Socialism with Chinese Characteristics in the New Era; "Double First-class" Construction; Establishing Learning for the People; Serving the Country; Seeking Truth from Facts and Striving Hard; Talent Cultivation; Thought Bank; International Influence; Beautiful Campus; People's Satisfaction; World Class.

Chinese characteristics; connotative development, reform and innovation; comprehensive; research; international influence; world-class university.

Hard work; Cohesion; Pursuit of excellence; National construction and economic and social development; Talent cultivation; Innovation; Internationalization; Distinctive; High level university in the world.

Xi Jinping Thought on Socialism with Chinese Characteristics for a New Era; Educational Excellence; Innovation; Specialization; Openness; New Industrialization Process in China; Chinese Characteristics; World-class University.

The university is a pioneer in the fields of national strategy, high-quality development, double-class construction, distinctive features, international influence, and high-level university.

Elite education; high-quality innovative talents; industry leaders; technical leaders and senior management talents; major national scientific and technological innovation tasks; national defense modernization; national economic and social development.

Science; innovation; diligence; social responsibility; high quality; masters and celebrities; talented students; wide cultural influence; world-class; research university.

Adhere to the direction of socialism; deep integration of finance, politics and law; distinctive features; world-class university; modernization of education; strong education; strong socialist modernization; Chinese dream of great rejuvenation of the Chinese nation.

Self-improvement; Realistic and Innovative; Xi Jinping Thought on Socialism with Chinese Characteristics for a New Era; Reform; Building Virtues for People; Serving Needs; Improving Quality; Pursuing Excellence; National Development Requirements; World Class; Distinctive Features; Research University

To establish moral education; to have global vision and national spirit; to be outstanding financial talents; to

U44 explore the truth; to help the people; to participate in public service; to pass on culture; to promote the progress of human civilization.

The education policy of the Communist Party of China; the direction of socialist schooling; the establishment of moral education; the "four services"; Chinese characteristics; world-class universities; the comprehensive development of moral, intellectual, physical, social and aesthetic development; the great rejuvenation of the Chinese nation.

Xi Jinping New Era Socialist Thought with Chinese Characteristics; Chinese Characteristics; World-class Struggle; Chinese Dream of Great Revival of the Chinese Nation. 


\section{Continued}

$\mathrm{U} 47$

Comprehensive; research-oriented; Chinese characteristics; world-class university; discipline development system; integrated schooling pattern; comprehensive reform.

Connotative development; wholeheartedly serving the people; nurturing people and cultivating talents;

U48 strengthening the military and expanding the people; leading by service; uniting and doing; establishing moral and cultivating people; distinctive features; first-class university.

Virtue to understand reason; learning to refine work; seeking truth from facts; Xi Jinping Thought on

U49 Socialism with Chinese Characteristics for a New Era; high quality; high level; rooted in the land of China; world-class university; Chinese dream of great rejuvenation of the Chinese nation.

Rooted in China; Serving national defense science and technology; National major strategic needs; National modernization; World scientific and technological progress; Adherence to mission; Reform and innovation; Cohesion; Pursuit of excellence; Chinese characteristics; World class university.

Table 2. High-frequency keywords for the mission of Chinese universities.

\begin{tabular}{|c|c|c|c|c|c|c|c|c|}
\hline $\begin{array}{c}\text { Serial } \\
\text { number }\end{array}$ & Keywords & Frequency & $\begin{array}{c}\text { Serial } \\
\text { number }\end{array}$ & Keywords & Frequency & $\begin{array}{c}\text { Serial } \\
\text { number }\end{array}$ & Keywords & Frequency \\
\hline 1 & First-class university & 68 & 18 & Times & 28 & 35 & First thoughts & 8 \\
\hline 2 & China & 66 & 19 & Excellence & 26 & 36 & Open & 8 \\
\hline 3 & World & 64 & 20 & Comprehensive & 24 & 37 & High Quality & 8 \\
\hline 4 & Subjects & 62 & 21 & People Satisfaction & 24 & 38 & Connotation & 8 \\
\hline 5 & Talent & 60 & 22 & Reform & 24 & 39 & Solidarity & 8 \\
\hline 6 & Featured & 54 & 23 & Hard Struggle & 22 & 40 & Earth & 6 \\
\hline 7 & Development & 48 & 24 & High Quality & 22 & 41 & Giving & 6 \\
\hline 8 & Social & 47 & 25 & High level & 20 & 42 & Awareness & 6 \\
\hline 9 & $\begin{array}{l}\text { Great rejuvenation of } \\
\text { the Chinese nation }\end{array}$ & 46 & 26 & Overall Development & 20 & 43 & Rigorous & 6 \\
\hline 10 & Innovation & 44 & 27 & Pursuit & 14 & 44 & take root & 6 \\
\hline 11 & Scientific Research & 42 & 28 & Education & 14 & 45 & Mission & 6 \\
\hline 12 & Self-improvement & 40 & 29 & Major & 12 & 46 & Ethnicity & 6 \\
\hline 13 & $\mathrm{Xi}$ Jinping & 38 & 30 & Spirituality & 12 & 47 & Cohesion & 6 \\
\hline 14 & Socialism & 36 & 31 & Impact & 10 & 48 & Knowledgeable & 6 \\
\hline 15 & Passing on the legacy & 36 & 32 & Demand & 10 & 49 & Objectives & 6 \\
\hline 16 & Services & 30 & 33 & Modernization & 10 & 50 & breast & 4 \\
\hline 17 & Practical work & 28 & 34 & Knowledge & 10 & 51 & Beautiful & 4 \\
\hline
\end{tabular}

degree of mission keywords was 36.566, and the average clustering coefficient was 0.802 . The keyword clustering network diagram based on cluster analysis is shown in Figure 1.

According to the cluster analysis chart, it can be seen that the key to the mission education of college students is the world, China, the great rejuvenation of 


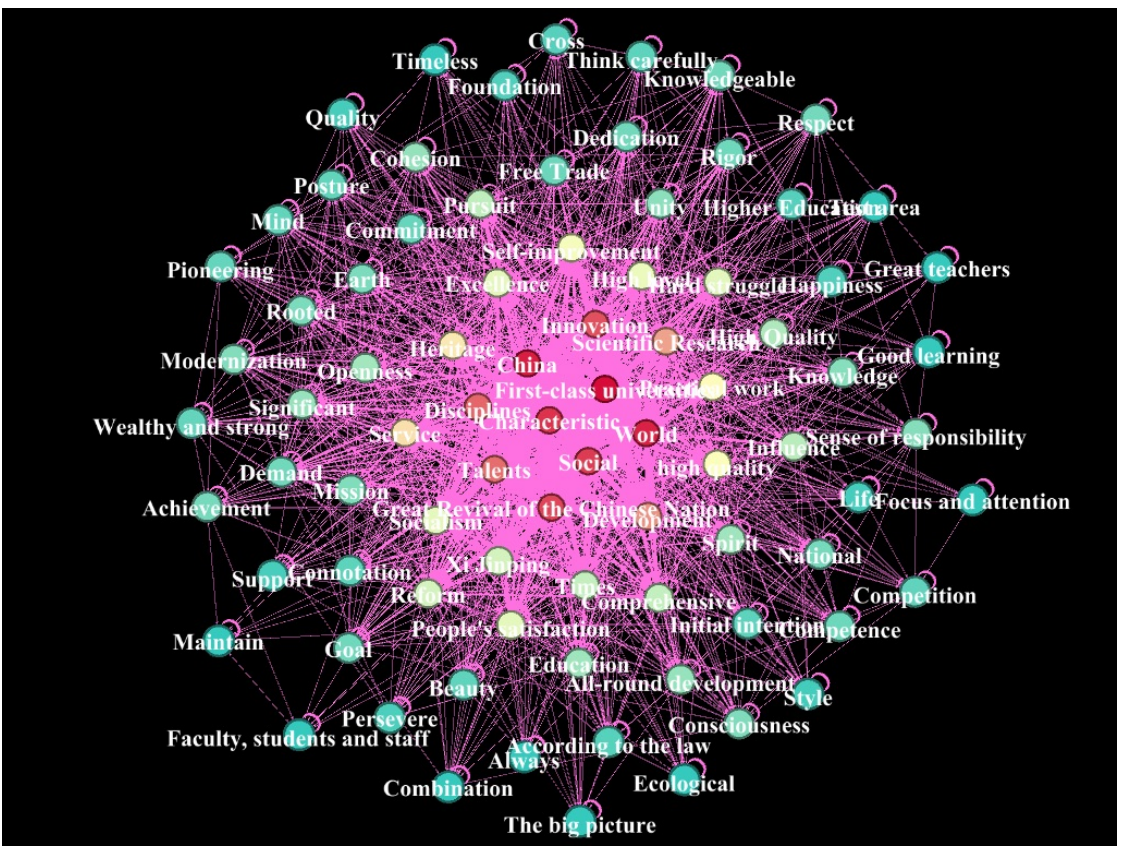

Figure 1. Clustering chart of key words describing the mission of Chinese college students.

the Chinese nation, society, first-class universities, disciplines, and talents. The fundamental goal is to innovate and reach the first-class level, and the premise is scientific research, reform and development. Combined with the specific description of the mission, the key words of world class, high quality, human civilization, internationalization, and international influence are attributed to the world mission. The key words such as rooted in China, serving national strategic needs, national defense science and technology modernization, strong country, and new era are attributed to the national mission. The key words of communist leadership, socialist direction, Xi Jinping's socialist thought of the new era, the Chinese dream of great rejuvenation of the Chinese nation, and the goal of "two hundred years" are summarized as the mission of political parties. The key words of economy, culture, reform, innovation foundation, general breakthrough, social responsibility, etc. are summarized as social mission. The key words such as connotation, characteristics, style, rule of law, comprehensive reform, research, image and beautiful campus are summarized as the mission of universities. Keywords such as cross-discipline, industry-university-research combination, academic, governance, pluralism, elite education, tradition, and opportunity are attributed to disciplinary mission. The key words of moral education, dedication, pragmatism, tolerance, striving, comprehensive development of moral, intellectual, physical, social and aesthetic development, high quality, high level, creativity and public service are attributed to the mission of talents. The above seven categories of world mission, national mission, political party mission, social mission, university mission, discipline mission and talent mission constitute the mission education system for college students in the new era, as shown in Figure 2. 


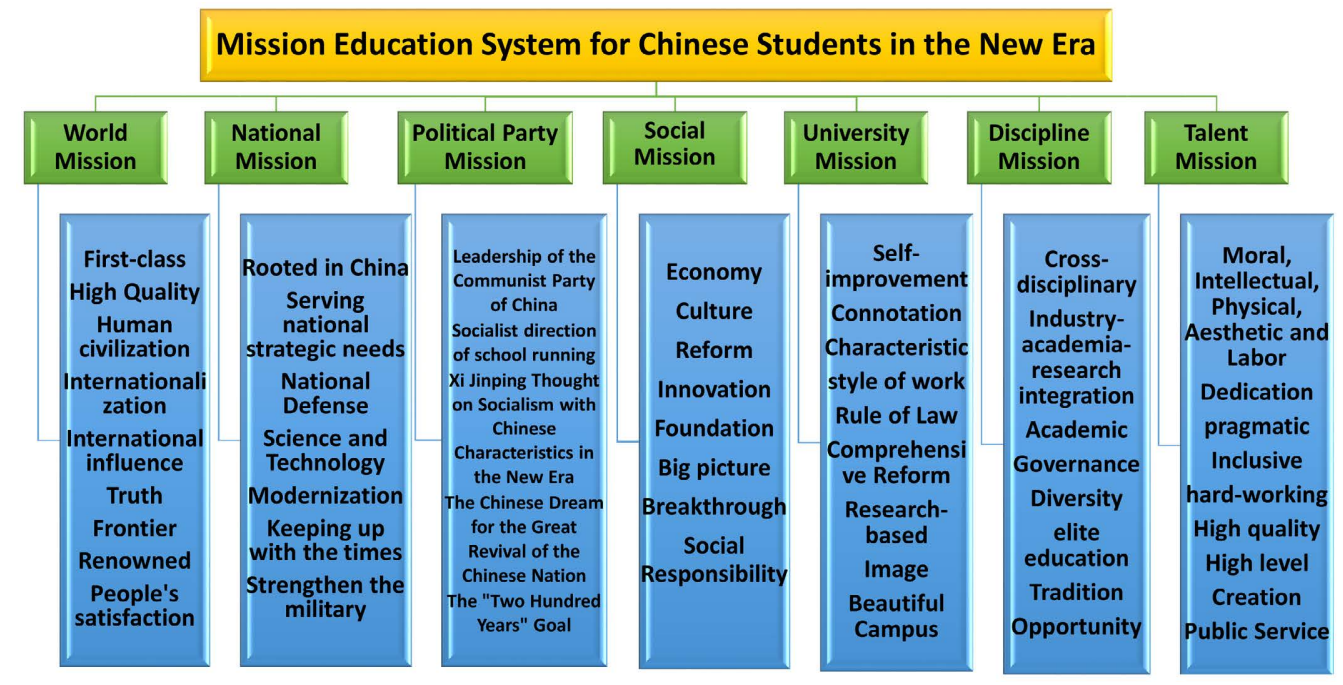

Figure 2. Mission education system of Chinese university students in the new era.

\section{The Development Path of Mission Education for College Students in the New Era}

It is crucial to carry forward the tradition in practice, continue the spiritual bloodline of the Chinese Communists, enhance the theoretical persuasion, practical transformation and value leadership of mission education for college students, and thicken the spiritual impetus for marching into the new journey and advancing into the new era. The author further studies the development path of mission education of college students in the new era according to the key words in the mission education system of college students in the new era, as shown in Figure 3.

\subsection{World Mission Education}

The world is facing the most profound and extensive changes, the open China is going to the world, the developing China must be integrated into the world (Zhai, 2014), and college students should have a world vision (Wang \& Lin, 2021).

\subsubsection{Forming a Sense of "Community"}

The essence of civilization is colorful, equal and inclusive; the relationship of civilization is communication, mutual appreciation and coexistence; the development of civilization is negotiation, co-construction and sharing; university students should learn to cooperate and win-win, be familiar with the history of human civilization development, form a consciousness of "community of human destiny", establish the goal of global governance, and realize benign space interaction.

\subsubsection{Developing a Sense of Influence}

University students should read more academic journals with the most international influence, learn about the world's frontier science, development processes, 


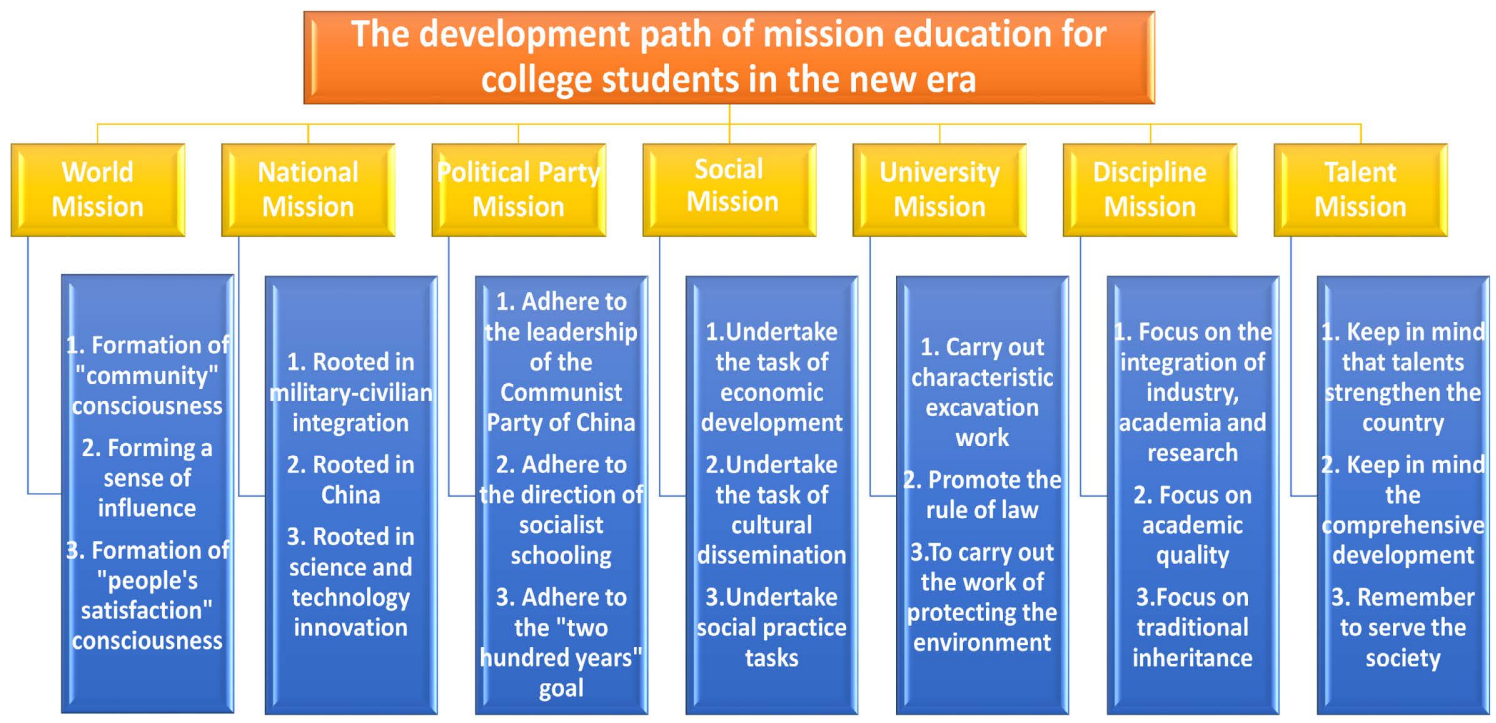

Figure 3. The development path of mission education for Chinese college students in the new era.

trends, and research methods, attend lectures by experts with international influence, enhance discourse by strengthening team building, public diplomacy, and institutional cooperation, and build high-impact results by focusing on key areas of science and technology innovation and forming fixed and temporary research teams.

\subsubsection{Formation of "People's Satisfaction" Awareness}

The core of socialism and Marxist political parties is "people's satisfaction", and the high-quality development of young talents needs to follow the concepts of innovative development, coordinated development, green development, open development and shared development, realize the comprehensive reform of target orientation, content structure, teaching mode and participating subjects, and re-examine the degree awarding system from the center of the people.

\subsection{National Mission Education}

Universities are closely related to the future and destiny of the country, and they must consciously lead and serve national development, consciously be at the forefront of social reform and national development and progress, and take the initiative to assume the mission and responsibility of promoting national knowledge and technological innovation.

\subsubsection{Rooted in Military-Civilian Integration}

The national environment needs to be stable, and it is extremely important to consolidate national defense and a strong army. Talents are the key factor to promote the high-quality development of our army and win the initiative in military competition and future warfare. College students should receive education on civil-military integration, draw wisdom and strength from it, inherit the red gene, forge the soul of a strong military, and participate in the process of 
achieving overall well-off, in the process of modernization, and in the process of realizing the Chinese dream of great rejuvenation of the Chinese nation.

\subsubsection{Rooted in China}

College students should be rooted in China's advanced political ideology and political system, in China's long history and glorious revolutionary tradition, in the basic national conditions and the reality of people's lives, and in the excellent traditional culture of the Chinese nation and the core values of socialism. Patriotism education and rule of law education are carried out to enhance college students' national identity, cultural identity and value identity, and to enhance their ability to actively serve the construction of major national strategies.

\subsubsection{Rooted in Science and Technology Research}

Encourage college students to actively participate in academic research and decision-making consultation, face the three major research directions of national decision-making, science and technology frontier and industrial development to study in a graded and classified manner, attach great importance to field research and practical operation, and solve the problems of cognition and judgment in the learning process. Keep abreast of the new development pattern in which the domestic grand cycle is the main body and the domestic and international double cycles promote each other, place innovation at the core of the overall situation of China's modernization, and achieve scientific and technological self-reliance and self-improvement.

\subsection{Political Party Mission Education}

The Chinese Communist Party has made outstanding contributions to the pursuit of national independence, people's liberation, national prosperity and people's happiness by uniting and leading the Chinese people, and university students must unswervingly adhere to and strengthen education on the mission of the Chinese Communist Party.

\subsubsection{Adherence to the Leadership of the Communist Party of China} University students should firmly uphold the CPC, understand that the leadership of the CPC is the most essential feature of socialism with Chinese characteristics, learn the CPC's governance system and ability to govern, learn the CPC's people-centered approach to overcoming various risk challenges and creating miracles, and reflect the Party's comprehensive leadership in all aspects and aspects of their studies.

\subsubsection{Adhere to the Direction of Socialist Schooling}

Adhering to the direction of socialist schooling is the fundamental principle that must be adhered to in the new era of higher education in China. Students should learn the "four services", integrate the ideological construction of the Party into the whole process of establishing moral education, adhere to the concept of service in terms of ideology, system, platform, guarantee and supervision, and 
strive for socialist modernization for life.

\subsubsection{Adhere to the "Two Hundred Years" Goal}

University students should firmly safeguard the security of state power, institutional security, ideological security, economic security, people's lives, social stability and security, pay attention to the main contradictions in society, the relationship between major countries, actively integrate themselves into the bright future of the "two hundred years" goal, firm ideals and beliefs, patriotic responsibility, dare to fight, and Work hard and work hard.

\subsection{Social Mission Education}

As socialism with Chinese characteristics enters a new era, social organizations have become an important force in all-round participation in national construction. College students should participate in the reform, development and innovation of social organizations.

\subsubsection{Undertake Economic Development Tasks}

In-depth study and understanding and implementation of Xi Jinping's economic thoughts on socialism with Chinese characteristics in the new era are necessary for college students to do well in employment and entrepreneurship. College students in the new era should form economic consciousness, understand the task of economic development, fully grasp the characteristics and development of local economic development, and integrate economic construction into the goal of talent training and the education management system.

\subsubsection{Undertake Cultural Communication Tasks}

Educate college students on cultural mission from the cross-cultural perspective, promote the international development of higher education and the mutual appreciation of Chinese and foreign civilizations. University students should establish the concept of internationalization, combine the regional advantages of universities with local culture, base on local culture, enhance cultural understanding, achieve cultural self-confidence, explore ways to spread culture, innovate cultural expression and enhance China's cultural soft power.

\subsubsection{Undertake Social Practice Tasks}

With the rapid progress of globalization, the inequality, conflict and exclusion of different countries and regions urgently need the mission education of social responsibility to alleviate, and should create the mission atmosphere of social responsibility practice for college students, clarify the social practice tasks, reform the social practice methods, cultivate the typical of taking charge, guide the network discourse, and activate the consciousness of college students to take responsibility and practice responsibility.

\subsection{Mission Education in Higher Education}

In the new era, to strengthen and improve the ideological and political work of 
colleges and universities, it is necessary to effectively review the situation, understand the way and plan the situation, cast the soul and build dreams, and form an interlocking and effective ideological chain.

\subsubsection{Carry out Characteristic Excavation Work}

The internal construction of the university is aimed at the high quality and high efficiency of school running, school governance and human education, and is closely related to the construction of a high-quality higher education system, tapping the development potential of the center of "teachers and students", giving full play to the autonomy, gathering the consensus of teachers and students, forming a strategic plan, improving the governance structure, improving the institutional system, tapping the special work, and promoting multi The Center has entered the deep water of comprehensive reform through cross-fertilization of disciplines.

\subsubsection{Conducting Rule of Law Advocacy}

Carry out education on the rule of law in colleges and universities with constitutional education as the core, comprehensively promote the rule of law, cultivate college students to establish awareness of the rule of law, learn the law, respect the law, abide by the law, use the law and defend their rights, promote the spirit of the rule of law, strengthen theoretical and practical research, and vigorously promote the integration of education on the rule of law with education on ideology and morality.

\subsubsection{Carrying out Environmental Protection Work}

College students' ecological civilization education and beautiful campus construction are aimed at cultivating rational "beautiful people", "ecological people" and "civilized people", so that students can systematically master the theory of beautiful campus and ecological The goal is to enable students to systematically master the theory of beautiful campus and ecological civilization, to have ecological and environmental protection awareness, ecological and environmental protection ethics, ecological and environmental protection legal knowledge, and ecological and environmental protection skills, to actively maintain the image of the campus, and to protect the environment and keep civilization at all times.

\subsection{Academic Mission Education}

Emphasis is placed on education of college students' disciplinary missions, breaking through traditional disciplinary boundaries, carrying out all-round practice, strengthening cooperation and exchange, and vigorously developing transferable skills.

\subsubsection{Focus on the Integration of Industry, Academia and Research} The disciplinary mission education of university students should strengthen disciplinary consciousness, advocate diversity, form a development mode of "focus - global”, “deep plowing - far-reaching", “crossover - innovation”, we encourage 
cross-disciplinary and industry-university-research integration, promote teachers' professional development, support students' practical innovation, inherit innovative industry culture, and cultivate innovative talents with industry characteristics.

\subsubsection{Focus on Academic Quality}

Emphasis is placed on the main status of college students' research, regulations and academic standards for academic research are formulated to guide college students to form positive and stable high-level academic emotions, to teach them the methods of academic research, to stimulate their desire to explore the truth, to stimulate their inner motivation for academic research, and to improve the quality of college students' academics, thus improving the quality of cultivation in general.

\subsubsection{Focus on Traditional Heritage}

Raise the awareness of university students about the importance of traditional heritage work, make overall planning and top-level design, clarify the tasks of traditional heritage work, implement research related to traditional heritage, innovate traditional heritage methods, strengthen the linkage with traditional heritage organizations in society, establish a sound heritage work system guarantee, seize the opportunities created by new media, and seek innovation in new challenges.

\subsection{Talent Mission Education}

The new round of scientific and technological revolution and industrial change is booming in the world today, and the value role of talents has become more prominent. Students in the new era should combine the Marxist concept of talent with Chinese practice and actively participate in the national strategy.

\subsubsection{Keep in Mind That Talent Is a Strong Nation}

Global talents are facing new challenges, and domestic talents development is also facing changes in the stage, status, tasks and pattern of talents development. Under the overall leadership of the Communist Party of China, university students must bear in mind the mission of strengthening the country with talents, clarify the strategic positioning of talent development, understand the goals of high-quality talent development, explore the methods and paths of talent governance, and seek their own breakthroughs in the existing talent system.

\subsubsection{Keep in Mind the Overall Development}

Entering the new era, the quality and scale of China's education has made historic achievements, and the comprehensive development of moral, intellectual, physical, social and aesthetic development has become the cultivation content of the education system. Investing in the comprehensive development of the five education, let high quality education return to life itself, return to life itself, cultivate the new era of high quality talents with excellent professionalism, high 
ideological awareness and moral cultivation.

\subsubsection{Remembering to Serve the Community}

The relationship between localization of university education and social service should go further, with a multi-pronged approach from the supply side, demand side, circulation, government regulation and intermediary role to generate more high-level creation, build innovative curriculum based on social goals, social resources and social evaluation, increase social investigation and social practice, and actively participate in social service.

\section{Conclusion}

In conclusion, this paper argues that Chinese college students must have systematic mission education and integrate mission education into ideological and political education to stimulate the real power source inside students from seven aspects: world mission, national mission, political party mission, social mission, university mission, discipline mission and talent mission. In addition to this, college students should also take up the responsibility for themselves and their families, actively exercise, and experience the affection with a grateful heart to achieve physical and mental health and family harmony. Based on the seven aspects, according to the logic of knowledge transmission and value guidance, we further explore the "seven threes" practical path of mission education for college students, namely, to form three consciousnesses for the world mission, to achieve three roots for the national mission, to achieve three insistencies for the political party mission, to achieve three undertakings for the social mission, to develop three missions for colleges and universities, to achieve three focuses for the discipline mission, and to achieve three focuses for the talent mission. The mission of talents should be remembered in three ways. Universities should make efforts to improve the relevance and effectiveness of mission education of Chinese students in the new era based on the mission education path, with $\mathrm{Xi}$ Jinping Thought on Socialism with Chinese Characteristics in the New Era as the guide to solve the contradictions and problems in the ideological and political education work of Chinese college students, take up the historical mission of the development of ideological and political education of college students in the new era, continuously enhance the guiding power and appeal of ideological and political education of college students in the new era, and make all college students become the guardians of defending the mission.

\section{Acknowledgements}

1) Jiangsu Province Education Reform and Development Strategic and Policy Research Major Project: Jiangsu high-level teacher team construction research, Project No. 202000206.

2) Project of Jiangsu Provincial Education Department: Research on talent management innovation of universities based on big data in the context of “double first-class", Project No. 72031941028A. 


\section{Conflicts of Interest}

The author declares no conflicts of interest regarding the publication of this paper.

\section{References}

Emini, F. T., \& Ayaz, C. E. (2020). An Analysis of Mission Statements of Higher Education Institutes in Terms of Innovation. Journal of Economics \& Administrative Sciences, No. 22, 89-100.

Flavin, M., Zhou, C. T., \& Quintero, V. (2020). Size Matters: An Analysis of UK Higher Education Institution Mission Statements. Journal of Higher Education Policy \& Management, 42, 285-299. https://doi.org/10.1080/1360080X.2019.1658839

Han, X. P., \& Yao, Z. (2021). The Historical Logic of the Communist Party of China's Institutional Construction of "Not Forgetting the Original Intention and Remembering the Mission". The Party Building and Ideological Education in Schools, No. 11, 4-7.

Huang, J., \& Wang, G. L. (2021). Theoretical Logic and Practical Progress of Mission Education for College Students. The Party Building and Ideological Education in Schools, No. 2, 84-86.

Li, W., \& Sun, X. L. (2021). A Brief Discussion on Mission Education for College Students in the New Era. The Party Building and Ideological Education in Schools, No. 18, 83-90.

Ostatnikova, D., Hopkins, M. A., Riles, T., Robinson, E., \& Hnilicova, S. (2019). Universities and Their Educational Mission in the 21st Century: Medical Education Innovations at Comenius University Faculty of Medicine. Bratislava Medical Journal, 120, 617-620. https://doi.org/10.4149/BLL 2019101

Wang, L., \& Guo, Z. T. (2020). Mission and Challenges of Higher Education: An Interview with G.Q. Max Lu, the President of the University of Surrey. National Science Review, No. 7, 1108-1113.

Wang, W. S. (2021a). Research on Mission Education in Colleges and Universities Based on Student Associations. The Party Building and Ideological Education in Schools, No. 16, 77-79.

Wang, X. J. (2021b). On Several Key Issues of Promoting the Innovation of the Ideological and Political Theory Courses in Colleges and Universities in the New Era. Studies on Marxist Theory, No. 7, 97-104.

Wang, Z. J., \& Lin, H. R. (2021). The Spatial and Temporal Logic and Empirical Inspiration of the Formation of the World's Top Universities. University Education Science, No. 1, 1-8.

$\mathrm{Xu}, \mathrm{H}$. (2021). Marx and Engels' Concept of Mission and Its Contemporary Value. Scientific Socialism, No. 1, 43-49.

Yu, G. H., \& Wu, S. P. (2020). Exploring the Professional Mission Education of College Students under the Vision of Craftsmanship. The Party Building and Ideological Education in Schools, No. 20, 62-69.

Zhai, Y. J. (2014). Universities Need to Carry Out “Ten Feelings" Education. China Higher Education, No. 17, 47-49.

Zhang, Y. (2021). The New Development Concept in the New Development Stage. Renming Luntan-Xueshu Qianyan, No. 13, 44-50. 